\title{
Multiple Personality Disorder of dr. Jang Choel in Partners for Justice Season 2 Movie
}

\author{
Rizky Mirani Desi Pratama ${ }^{1}$, Wiruma Titian Adi $^{2}$ \\ ${ }^{1}$ Universitas Bina Sarana Informatika \\ e-mail: rizky.rrr@bsi.ac.id \\ ${ }^{2}$ Universitas Bina Sarana Informatika \\ e-mail: wiruma.wmt@bsi.ac.id
}

\begin{abstract}
Cara Sitasi: Pratama, R. M. D., \& Adi, W. T. (2019). Multiple Personality Disorder of dr. Jang Choel in Partners for Justice Season 2 Movie. Wanastra, 11(2), 167-172.
\end{abstract}

\begin{abstract}
The objective of this research is to find out how multiple personality of dr. Jang Choel shown in Partners for Justice Movie Season 2 and the cause of the multiple personality disorder. dr. Jang Choel is a new character that appears in Partner for Justice Movie Season 2. He is a doctor that suffered multiple personality disorder. His real personality and his artificial personality is very different. This research uses descriptive qualitative method and library research. The research shown that the real personality of dr. Jang is kind a warm person, but he will show his other personality which is dr.K if he remembers his childhood traumatic. The cause of his multiple personality disorder is physical abuse that performed by his mother. He also experienced traumatic of closed and dark place because he always locked by his mother in the bathroom when he made a mistake. This incident made him create a new personality that is stronger than his real personlity to overcome his fears.
\end{abstract}

\section{Keywords: Personality Disorder, Partner for Justice Season 2, Psychology}

\section{INTRODUCTION}

Literature is a literary work that tells an event. Sometimes literature also tells the author's feelings. Literary works can be based on experience or from the imagination of the author. Then, literary works can be classified based on whether it is poetry, novel, movie, drama. Film is a literary work. The film was taken as the object of analysis in this paper. Compared to other forms of entertainment, people find that movies are more fun because movies can help people make their imagination real and invite people to see new things they never imagined before.

Nowadays, literature scope has envolved. Literature relates with other disciplines for example, science of psychology, sociology, medical science, and others. In the film Partners for Justice season 2, the writer found literary works related with psychology. One of the characters in the Partners for Justice season 2, suffers psychological illness, namely Multiple Personality Disorder.

Partners for Justice season 2 is a continuation of the first session. This series is part two which tells about prosecutors and forensic doctors who have bad personalities. The drama tells the story of a warmhearted prosecutor with a bad personality forensic scientist who must join forces to catch criminals. A forensic doctor named Baek Bum has doubts about the death of Oh Man Sang. Baek Bum then tries to uncover the truth whether Oh Man Sang is really dead or not. Meanwhile, Eun Sol has grown from a beginner prosecutor and still works with Baek Beom. Do Ji Han is a prosecutor who works with Baek Bum and Eun Sol. This drama is even more exciting with the presence of Dr. Jang Choel that is told suffers from a psychological illness that is multiple personality.

Based on Bressert (2019) Dissociative identity disorder (DID) is a diagnosis characterized by having two or more distinct people, each with his or her own identity and personality, that alternately take control over a person. More commonly known by its older name, multiple personality disorder. It is thought that this disorder may be caused by trauma from a person's childhood, such as ongoing physical abuse, sexual assault, and/or emotional abuse.

This research wants to find out how Multiple Personality Disorder of Dr. Jang Choel is shown in Partners for Justice Season 2 Movie. What the symptoms that are shown and the causes of Multiple Personality Disorder that is suffered by Dr. Jang Choel.

\section{Movie}


Movie is a connected story that is played by some characters that can be human or animal. As stated by Hans (2008:8) "Movie is all connected throughout a story with several actors: human or animals, cartoony, realistic or very stylized and, with lots of emotions, action and fantastic worlds. People are part of a creation process in which a dream world comes alive."

According to Mary H. Snyder (2011:11) that, "Like the drama, the movie is a visual, herbal, and aural medium presented before a theater audience." It means movie similar with drama that show an audio-visual entertainment.

\section{Character}

According to Shaffer (2008:131), "a character is a person (or being given the characteristics of a person) who appears in, acts and/or speaks in, narrators or is referred to in a literary work." It means character is person or animal or something that given characteristic of a person that play in a story or literary works. Same statement comes from Kennedy and Giola (2010:76), “A character, then, is presumably an imagined person who inhabits a story although that simple definition may admit to a few exceptions."

\section{Main Character}

The main character is a character who is preferred in a story. usually the main character becomes the core of a story and many appear in a story. As Beaty, et al (2002:100) states, "The major or main characters are those we see more of over longer period time; we learn about them, and we think of them as more complex and, therefore, frequently more "realistic" than the minor characters, the figure who fill out the story." The same opinion also explained by Nurgiyantoro (2011:176-177) "Tokoh utama adalah tokoh yang diutamakan penceritaannya dalam novel yang bersangkutan.Ia merupakan tokoh yang paling banyak diceritakan, baik sebagai pelaku kejadian maupun yang dikenai kejadian." (Main character is a character in the novel that has the most important role. He or she is the most telling figure, both as perpetrators of the incident or vice versa)

Another source DiYanni (2004:54) states that "Major character is an important figure at the center of the story's action or theme." It refers to the people who take part in most of the events to develop a story and resolve the conflicts in novel or drama.

\section{Multiple Personality Disorder}

Based on Bressert (2019) Dissociative identity disorder (DID) is a diagnosis characterized by having two or more distinct people, each with his or her own identity and personality, that alternately take control over a person, more commonly known by its older name, multiple personality disorder. It is thought that this disorder may be caused by trauma from a person's childhood, such as ongoing physical abuse, sexual assault, and/or emotional abuse.

Bressert (2019) added that Dissociative identity disorder is characterized by the following symptoms, which can be diagnosed by a mental health professional:

a. Disruption of a person's identity. This disruption can be seen by the presence of two or more distinct personality states. In some cultures, these different personality states may be called "possession" or label the person as being "possessed." The disruption involves marked discontinuity in sense of self and sense of agency, accompanied by related alterations in affect, behavior, consciousness, memory, perception, cognition, and/or sensory-motor functioning.

b. Recurring gaps in the recall of everyday events, important personal information, and/or traumatic events are are inconsistent with ordinary forgetting.

c. These symptoms cause significant distress and/or impairment in the the person's everyday functioning with friends, family, at work or school, or in other important areas of their life.

d. These symptoms are not a part of a broadly accepted cultural or religious practice. In children, they should not be confused with imaginary play, role playing, or fantasy play.

e. The disturbance is not due to the direct physiological effects of a substance (e.g., blackouts or chaotic behavior during alcohol intoxication) or a general medical condition (e.g., complex partial seizures).

Rob and Carolyn Spring (2010) described about the symptom of dissociative identity disorder. There are different types of dissociative disorder and they may include varying degrees of the following five core dissociative identity disorder symptoms:

a. Amnesia. This will be for specific and significant blocks of time that have passed -gaps in memory or 'lost time'.

b. Depersonalization. This is a feeling of being detached from yourself or looking at yourself almost from the outside, as an 
observer would. It can also include feeling cut-off from parts of your body or detached from your emotions.

c. Derealisation. This is a feeling of detachment from the world around you, or a sense that people or things feel unreal

d. Identity confusion. This is a feeling of internal conflict of who you are - having difficulty in defining yourself.

e. Identity alteration. This is a shift in identity accompanied by changes in behavior that are observable to others. These may include speaking in a different voice or using different names. This may be experienced as a personality switch or shift, or a loss of control to 'someone else' inside.

Mostly, multiple personality disorder caused by childhood trauma. The person who suffer multiple personality disorder build a new personality that usually stronger that their real personality to overcome the trauma. Carr (2001:129) stated that "Dissociative identity disorder or multiple personality disorder being the most extreme dissociation. More extreme dissociative conditions develop when the person has a strong capacity to dissociate and is exposed repeatedly to severe trauma". In addition, Weseley and McEntarffer (2010:244) stated: Dissociative Identity Disorder (DID), formerly known as multiple personality disorder, is when a person has several personalities rather than one integrated personality. Someone with DID can have any number of personalities. The different personalities can represent many ages and both sexes. Often, two of the personalities will be the opposite of each other. People with DID commonly have a history of sexual abuse or some other terrible childhood trauma.

\section{METHOD OF RESEARCH}

This research uses qualitative descriptive method and library research. The writers find out some theories that are needed from internet, book, and article. The data used are pictures and dialogues in Partners for Justice Season 2 movie. There were some procedures done by the writers. First the writers watched Partners for Justice Season 2 movie. Second, the writers collected dialogue and pictures as Data. Third they analyzed the data based on the theories of multiple personality disorder. As mentioned above, this research only find out how multiple personality dissorder shown in Partners for Justice Season 2 movie and cause of multiple personality disorder that suffered by Dr. Jang Choel in Partners for Justice Season 2 movie.

\section{FINDING AND RESULT}

\section{Multiple Personality Dissorder of dr. Jang Choel}

Dr. Jang Choel is one of characters in Partners for Justice Season 2 movie. dr. Jang Choel is a surgical doctor at Hanjoo Hospital. dr.Jang Choel is a very good doctor and tends to be closed or introvert. But, there are a number of occasions where dr. Jang Choel has a 180 degree different personality with his original personality.

The Doctor saved a little girl named Soe Hyun when she had a car accident. dr. Jang even helped the police to find out the person who hit Soe Hyun. This become the first meeting between dr. Jang with Soe Hyun and her mother.

Dr. Jang is a warm person, especially towards children. He even accepted Soe Hyun's invitation to attend her birthday party even though he was very busy.

Soe Hyun

: Right, Dr. Jang. I'm having a birthday party this Saturday. Do you want to come?

Soe Hyun's Mom : Seo Hyun, he's busy. It's okay, Dr. Jang. Don't mind her.

Soe Hyun : It would be great if you could come.

Soe Hyun's Mom : Seo Hyun, why do you suddenly say that?

Soe Hyun : I never had a birthday party with my dad before.

Soe Hyun's Mom : What's with you?

dr. Jang Choel : I'll be there. At your birthday party.

Soe Hyun : Really?

Soe Hyun's Mom : Dr. Jang. She's just a kid. Don't mind what she says.

dr. Jang Choel : It's all right.

Dr. Jang always fulfill all of Soe Hyun's wishes including when Soe Hyun wants to have a picnic with dr. Jang and his mother. In this scene, dr. Jang Choel looks very soft and kind. He was very kind to Soe Hyun, even when Soe Hyun asked him to do a funny face, he agreed and did it. He really enjoyed time with Soe Hyun and his mother because he felt the warmth of the family if he was with them. Dr. Jang Choel also saved Soe Hyun when Soe Hyun was held captive in a closed and dark place. He was even willing to sacrifice to save Soe Hyun, even though dr. Jang Choel knew that he afraid of the dark or had phobia with dark and closed place. He got phobia because a closed and dark place would make him remember his past that left him traumatized. 
dr. Jang Choel : Seo Hyun! Seo Hyun, are you okay?

Dr. Jang besides good to Soe Hyun, dr. Jang choel is also a good doctor for his patient in Hanjoo hospital. He even helped a seriously injured accident patient and tried his best to save the patient. Unfortunately, the patient died. This made dr. Jang Choel disappointed because he could not save the patient.

In the first impression of dr. Jang which looks like a kind and warm person but there is a secret behind it. dr. Jang Choel has other personality that is very different from his personality. He called his other personlity dr. K. He has strong, cold and brave characteristic even can abuse or kill someone, it is very different with his original characteristic that is kind and soft. dr. K's characteristic will appear if dr. Jang Choel remember about his past, when his mother locked him in the bathroom. And dr. K knows that he is different with dr. Jang Choel. It can be seen from dialogue below.

Prosecutor Do : What are you doing, Jang
Cheol?

Dialogue below also reveal that dr. Jang Choel had multiple identity disorder.

\section{dr. Baek Beom : Baek Beom speaking. \\ Prosecutor Do : It's me, Do Ji Han. \\ dr. Baek Beom : Hey, are you okay? What happened? \\ Prosecutor Do : I'm fine. I'll tell you the details later. Before that, did you know that...Jang Cheol had a multiple personality disorder? \\ dr. Baek Beom : Did you see him change in person? \\ Prosecutor Do : Yes, he turned into a individual. How is that possible?}

dr. Baek Beom : DID tends to be triggered...by childhood traumas.

Multiple identity disorder that suffered by dr. Jang Choel is very dangerous. The character dr. K even can kill dr. Jang Choel's mother which is dr.K's mother. It shown when dr. K communicate with dr. Jang Choel. This scene also shows that dr. Jang Choel's experience depersonalization. This is a feeling of being detached from yourself or looking at yourself almost from the outside, as an observer. It can also include feeling cut-off from parts of your body or detached from your emotions
Dr.Jang Choel : You killed her, didn't you? It was you...who killed Mom, right?

Dr. K : Yes. I killed her. But...she died ages ago. Did you just find that out?

Dr. $\mathrm{K}$ is also able to do criminal act even killing several people, where the action will not be possible by Dr. Jang's Choel personality. The first dr. K set the murder of a woman in a motel. Even though the woman had died before, but dr. $\mathrm{K}$ made it as if it were serial murder. Then dr. K put a foot piece in a public toilet to ensure that this event was truly a serial murder and disturbed the entire Seoul citizen. This incident also made Seoul's police busy.

Dr. Jang hang the bodies of women in empty buildings to fool Korean police. The scene of this fake case was made to keep the police busy and think that this incident related with the previous murder. This make the police and prosecutor assume that it was a serial murder. dr. Jang seems to be happy for his action.

$\begin{array}{ll}\text { Prosecutor Eun :Yes, Detective Kang. What } \\ \text { did you say? Okay, we'll go } \\ \text { there immediately. } \\ \text { Detective } & : \text { What is it? What did he say? } \\ \text { Prosecutor Eun } & : \text { At a neighborhood park in } \\ & \text { Bango-dong, a substantial } \\ & \text { amount of blood was found. } \\ \text { Detective } & : \text { Blood, not bloodstain? }\end{array}$

dr. $\mathrm{K}$ also killed a prosecutor who tried to investigate a case which related to him. He killed the prosecutor and then made the murder as if it was an accident. He made like the prosecutor died from being bitten by rattlesnake. dr. K lock up and tortur prosecutor Do because prosecutor Do tried to investigate the murder carried out by Dr. K. Prosecutor Do also had known who is dr. K. dr. K tie the prosecutor Do's legs and arms and hang Prosecutor Do. In this scene, it shows that dr. k does not have conscience.

\begin{tabular}{|c|c|}
\hline Prosecutor Do & : Aren't you Doctor K? \\
\hline dr. K & : Bingo \\
\hline Prosecutor Do & $\begin{array}{l}\text { : Why did you kill Young Soo? } \\
\text { He had nothing to do with you. }\end{array}$ \\
\hline dr. $K$ & $\begin{array}{l}\text { : Well, I can't bring him back } \\
\text { from the dead. }\end{array}$ \\
\hline Prosecutor Do & $\begin{array}{l}\text { : Killing people is like a joke to } \\
\text { you, isn't it? }\end{array}$ \\
\hline
\end{tabular}


dr. $K$

: Does this look like a joke to you? I gave this plan a lot of thought, you know.

Prosecutor Do : Young Soo, He was going to be a father soon.

dr. K : Stop it.

Prosecutor Do : Why?Are you getting all soft at the mention of his child?

dr. K : Shut your mouth!

Prosecutor Do : That child will grow up without a father because of you. He will never get to see his father...

dr. K : I told you to shut your mouth!

Prosecutor Do : Why? Is it because you grew up without a father too?

Beside experiencing depersonalization, dr. Jang also experienced amnesia. This will be for specific and significant blocks of time that have passed -gaps in memory or 'lost time'. From the scene below we know that sometime dr. Jang lost his memory or forgot all his action when he becoming dr. K. dr. K always draws something that he did in order dr. Jang Choel can figure it. In dr. K's diary, there are his crime drawing. He draws all of crime that he has done.

Prosecutor Do : Isn't this.Young Soo's crime scene?

NFS Staff : It's... It's a snake. Is he responsible for that incident as well? But... But there was snake venom. Did he release a snake there and let it bite him?

dr. Baek Beom : Do you want to try it?

NFS Staff : No, thanks. I think I made a rash assumption. I'm sorry.

Prosecutor Do : The spree killing. The rope used for hanging. The layout of the toilet where blood was found. The fuel that was used for the arson.He also knew the incident at Sunghoo Motel took place.in Room 407. All of this...wasn't disclosed to the public.

\section{The Cause of Multiple Personality Disorder}

Weseley and McEntarffer (2010:244) stated that commonly the cause of Multiple Personality Disorder or Dissociative Identity Disorder is Childhood trauma. The writer found that the cause of multiple personality disorder that dr. Jang Choel suffered is his childhood trauma. dr. Jang Choel has experienced physical abuse committed by his mother. dr. Jang Choel was always been locked by dr. Jang's mother in the bathroom when dr. Jang made a mistake. This made dr. Jang experiencing trauma when he was in a dark and closed place. The violence committed by his mother also made dr. Jang created a new personality that is stronger than his original personality, that is $\mathrm{dr}$. $\mathrm{K}$.

dr. Jang Choel: Mom... Mom! Mom, I'm sorry. Mom! Mom...Mom, please...- Mom, let me out. - Mom, open the door. Mom, please spare me.Mom, let me out. Mom. Mom.

dr. Jang Choel's mother: Did you pee again? I told you not to pee. Take off your clothes! Come here! I'll cut it off! I'll cut off everything! I'll cut everyone who lies!

dr. Jang Choel: Mom, please spare my life. Mom, please.

dr. Jang Choel's mother : Go away! I don't want to see you! Mom...Mom. Mom, there is someone over here. Mom, there is someone here.

dr. Jang Choel: Please open the door, Mom. Mom...Mom, there is someone here. Mom, there are bugs here! Mom! Mom! Mom, there are bugs on my body! I'm scared. Please open the door.

When dr. Jang was a kid, his life suffered a lot. At the time of dr. Jang's birthday, he just celebrated with his mother at his home. His mother just told him to blow out candles without singing a birthday song first. His mother even yelled at him to blow out the birthday candle and turned her back on him.

Personality of dr. $\mathrm{K}$ is stronger than dr. Jang Choel. dr. $\mathrm{K}$ declared that he is different from dr. Jang Choel who is too weak and always cried in the bathroom.

Prosecutor Do : What are you doing, Jang Cheol?

dr. Jang Choel : Didn't Mr. Baek tell you?Isn't this our first time meeting?

Prosecutor Do : Who are you?

dr. jang Choel : Gosh, that punk, Jang Cheol is too weak.He's just like that kid who cried in the bathroom, locked up.But...I'm different from him.

\section{CONCLUSION}

The multiple personality disorder that dr. Jang Choel suffered can be seen from the changes of his attitude and personality. dr. Jang's original personality is kind and warm surgeon, while the 
other personality, in this case is dr. $\mathrm{K}$ is very malicious, harsh and avengeful.

The cause of dr. Jang Choel multiple personality disorder is childhood trauma. Physical abuse that committed by his mother forced him to build a new personality that stronger than his original personality.

\section{REFERENCES}

Beaty, Booth, et al. 2002. The Norton Introduction to Literature (shorter eight edition). New York: W.W. Norton \& Company.

DiYanni, Robert. 2004. Literature: Approaches to Fiction, Poetry and Drama. New York: McGraw-Hill Companies.

Hans, Bachen P. 2008. Dream Worlds Production Design in Animation. Oxford: Oxford Elsevier, Ltd.

Kennedy, X.J and Dana Gioia. 2016. Literature: An Introduction to Fiction, Poetry, Drama, and Writing, $13^{\text {th }}$ Edition..Pearson: North Carolina

Nurgiyantoro, Burhan. 2011. Teori Pengkajian Fiksi. Yogyakarta: Gajah Mada University Press.

Snyder, H. Mary. 2011. Western Movie References In America Literature. Educational Leadership, Washington, D.C.

Shaffer, Christina Myers. 2006. Barron's SAT Subject Test Literature. New York: Barron's Educational Series.

Rob and Carolyn Spring.2010. An Introduction to Dissociative and Dissociative Identity Disorder. taken from :http://www.podsonline.org.uk/introtodid.htm 1.(23 May 2013)

Weseley, Allyson.J and Robert McEntarffer. 2010. Barron'a AP Psychology. New York: Barron's educational Series Inc.

\section{PROFIL PENULIS}

Rizky Mirani lahir di Cilacap, 10 Desember 1989. Lulus tahun 2016 pada jurusan Master Pendidikan Bahasa Inggris Universitas Indraprasta PGRI. Mengajar di program studi bahasa Inggris Universitas Bina Sarana Informatika sejak tahun
2012.

Wiruma Titian Adi lahir di Semarang 21 September 1975. Lulus tahun 2001 di Program Magister Manajemen Universitas Diponegoro Semarang. Mengajar di program studi Bahasa Inggris Universitas Bina Sarana Informatika seja tahun 2008. 